\title{
EFEKTIVITAS PENGGUNAAN METODE BUZZ GROUP DALAM PEMBELAJARAN MENULIS RESENSI CERITA PENDEK DI KELAS XI SMK NEGERI 3 SINGARAJA
}

\author{
Desak Nyoman Sri Yogini ${ }^{1}$, I Gede Nurjaya ${ }^{2}$, Sang Ayu Putu Sriasih ${ }^{3}$ \\ ${ }^{123}$ Jurusan Pendidikan Bahasa dan Sastra Indonesia \\ Fakultas Bahasa dan Seni \\ Universitas Pendidikan Ganesha \\ Singaraja, Indonesia \\ e-mail :\{desaksriyogini02@gmail.com ${ }^{1}$, gedenurjaya@gmail.com² $^{2}$ \\ sap.sriasih@yahoo.com ${ }^{3}$
}

\begin{abstract}
ABSTRAK
Penelitian ini bertujuan untuk (1) mendeskripsikan prestasi siswa dalam pembelajaran menulis resensi cerita pendek dengan menggunakan metode buzz group, (2) mendeskripsikan respons siswa terhadap penggunaan metode buzz group dalam pembelajaran menulis resensi cerita pendek, dan (3) mendeskripsikan kendala-kendala yang dihadapi oleh guru dan siswa saat menggunakan metode buzz group dalam pembelajaran menulis resensi cerita pendek. Penelitian ini menggunakan rancangan penelitian deskriptif kualitatif dan deskiptif kuantitatif. Subjek penelitian ini adalah guru dan siswa kelas XI SMK Negeri 3 Singaraja. Objek penelitian ini yaitu penggunaan metode buzz group dalam pembelajaran menulis resensi cerita pendek. Metode pengumpulan data yang digunakan adalah metode observasi, tes, angket/kuesioner, dan wawancara. Data yang diperoleh dianalisis dengan teknik analisis deskriptif kualitatif dan deskriptif kuantitatif. Hasil penelitian ini menunjukkan bahwa (1) siswa memperoleh prestasi yang baik dengan digunakannya metode buzz group. Dari 121 orang siswa, sebanyak 91 orang siswa $(75.22 \%)$ mendapatkan nilai dengan kategori baik, (2) hasil kuesioner menunjukkan, dari 121 orang siswa, sebanyak 80 orang siswa (66.13\%) memberikan respons positif terhadap penggunaan metode buzz group dalam pembelajaran menulis resensi cerita pendek, dan (3) kendala-kendala yang dihadapi oleh guru dan siswa saat menggunakan metode buzz group yaitu dari segi waktu, lingkungan belajar, sedangkan kendala-kendala yang dihadapi siswa yaitu dari segi waktu dan konsentrasi belajar. Penggunaan metode buzz group ini efektif digunakan dalam pembelajaran menulis resensi cerita pendek.
\end{abstract}

Kata Kunci : cerita pendek, menulis, metode buzz group, pembelajaran, resensi

\section{ABSTRACT}

This study aimed to (1) describe the students' achievement in short story review writing by using the buzz group method, (2) to describe the student's response to the use of buzz group method in short story review writing, and (3) to describe the struggles faced by teachers and students when using the buzz group method in short story review writing lessons. This research uses descriptive qualitative and descriptive quantitative research design. The subjects of this study were teachers and students of grade XI SMK Negeri 3 Singaraja. The object of this research was the use of buzz group method in learning writing short story reviews. Methods of data collection used were the method of observation, 
test, questionnaire, and interview. The data obtained was analyzed by qualitative descriptive and descriptive quantitative analysis. The results of this study indicated that (1) students got good achievement with the use of buzz group method. From 121 students, 91 students $(75.22 \%)$ got good grades, (2) result of questionnaire showed that from 121 students, 80 students (66.13\%) responded positively to the use of buzz group method in learning writing short story reviews, and (3) struggles faced by teachers and students when using the buzz group method were in terms of time and student learning environment, while struggles faced by students of time and concentration of learning. The use of the buzz group method was effectively used in short story review writing lessons.

Keywords: short stories learning, writing, buzz group methods, learning, reviews

\section{PENDAHULUAN}

Bahasa merupakan salah satu alat komunikasi yang digunakan oleh manusia untuk berinteraksi dalam kehidupan seharihari. Sebagai alat komunikasi, bahasa memungkinkan setiap orang untuk menyesuaikan diri dengan lingkungan fisik dan lingkungan sosialnya serta memungkinkan untuk mempelajari kebiasaan, adat-istiadat, kebudayaan, dan latar belakang masing-masing (Keraf, 2004:6). Saat berinteraksi, seseorang menggunakan bahasa untuk mengekspresikan apa yang ada di dalam pikirannya. Komunikasi yang efektif dapat terjalin, jika menggunakan bahasa yang baik dan benar. Oleh karena itu, manusia dituntut untuk terampil dalam berbahasa demi terjalinnya komunikasi yang efektif.

Harris (dalam Wendra, 2012:7) menyatakan bahwa keterampilan berbahasa mempunyai empat komponen yaitu (1) keterampilan menyimak, (2) berbicara, (3) membaca, dan (4) menulis. Keempat komponen keterampilan berbahasa tersebut merupakan kesatuan yang utuh. Keterampilan berbahasa di atas saling berkaitan dalam KBM (kegiatan belajar-mengajar) di kelas. Hal-hal yang diperoleh dari kegiatan menyimak, berbicara, membaca, akan memberikan kontribusi yang banyak dalam kegiatan menulis begitu pula sebaliknya, apapun yang diperoleh dari kegiatan menulis akan berpengaruh terhadap ketiga aspek kemampuan berbahasa lainnya.

Keterampilan menulis merupakan salah satu bentuk keterampilan berbahasa yang memiliki tingkatan paling tinggi di antara keterampilan berbahasa lainnya. Hal tersebut dikarenakan dalam menulis seseorang harus mampu mengungkapkan

gagasan, maksud, ide, pesan, ataupun pemikirannya kepada orang lain.

Pada prinsipnya menulis merupakan salah satu kegiatan mengungkapkan gagasan-gagasan melalui media tulis. Hal tersebut didukung oleh pendapat Nurudin (dalam Barnawi \& Arifin, 2016:14) yang menyatakan bahwa menulis adalah kegiatan yang dilakukan oleh seseorang untuk menghasilkan tulisan. Lain halnya dengan pendapat Arifin dan Kusrianto (dalam Barnawi \& Arifin, 2016:14) yang mengungkapkan bahwa menulis adalah tindak komunikasi yang pada hakikatnya sama dengan berbicara. Kesamaan itu terletak pada tujuan dan muatannya. Tujuan menulis atau berbicara adalah untuk menyampaikan sesuatu kepada orang lain, sedangkan muatannya adalah berupa pikiran, perasaan, gagasan, pesan, dan pendapat. Morsey (dalam Tarigan, 1997:4) menyatakan bahwa menulis merupakan serangkaian kegiatan yang digunakan orang-orang terpelajar untuk mencatat atau merekam, meyakinkan, melaporkan, atau memberitahukan, dan memengaruhi.

Dari ketiga pendapat ahli tersebut, dapat ditarik satu kesimpulan mengenai pengertian menulis. Menulis merupakan tindak komunikasi yang digunakan oleh seseorang untuk mencatat atau merekam, meyakinkan, melaporkan, atau memberitahukan, dan memengaruhi melalui bahasa tulis, sehingga dapat dipahami oleh pembaca. Pada dasarnya, kegiatan menulis 
sangat diperlukan dan memiliki peranan yang penting. Menulis dikatakan penting karena menulis merupakan suatu proses yang teratur. Hal ini mengimplementasikan bahwa kegiatan menulis membutuhkan pemikiran yang luas. Sebagai suatu proses, menulis mencakup kegiatan mulai dari penemuan gagasan atau topik yang akan dibahas sampai dengan penulisan konsep akhir. Pendapat tersebut didukung oleh Akhadiah (1998:29), bahwa proses tersebut mencakup beberapa tahap, yaitu tahap persiapan atau tahap prapenulisan, penulisan, dan revisi, sehingga tulisan yang dihasilkan mudah dipahami oleh pembaca. Salah satu wujud keterampilan menulis adalah menulis resensi.

Menurut Keraf (1980:274), resensi adalah suatu tulisan atau ulasan mengenai nilai karya sastra atau buku. Tujuan resensi adalah menyampaikan kepada pembaca apakah karya yang dikomentari dan dibincangkan itu patut mendapat sambutan dari pembaca atau tidak. Sementara itu, resensi dapat juga dikatakan sebagai suatu komentar atau ulasan seorang penulis atas sebuah hasil karya, baik buku, film, karya seni, maupun produk yang lain. Misalnya, buku karya ilmiah, laporan hasil penelitian, majalah ilmiah, novel, cerpen, drama/lakon, dan sejenisnya dapat diresensikan (Arifin, dkk, 2008: 235). Dalam Kurikulum 2013 menulis resensi, khususnya resensi cerpen merupakan salah satu kompetensi yang harus dikuasai oleh siswa.

Kurikulum 2013 edisi revisi 2017 untuk siswa kelas XI SMA/SMK, menulis resensi khususnya resensi cerpen merupakan salah satu kompetensi yang harus dikuasai oleh siswa. Hal ini terdapat dalam silabus bahasa Indonesia yaitu dengan kompetensi dasar (KD) aspek pengetahuan menganalisis kebahasaan resensi setidaknya dua karya yang berbeda dan kompetensi dasar (KD) aspek keterampilan mengkonstruksi sebuah resensi dari buku kumpulan cerita pendek atau novel yang sudah dibaca.

Menulis resensi merupakan salah satu upaya memperkenalkan suatu buku kepada orang lain yang belum membaca buku, sehingga setelah membaca resensi orang tersebut tergerak hatinya untuk membaca karya orang lain. Resensi buku juga merupakan salah satu cara meningkatkan minat baca terhadap buku. Oleh karena itu, keterampilan menulis resensi cerpen harus dikuasai oleh siswa, karena merupakan salah satu kompetensi dasar yang harus dicapai. Keterampilan menulis resensi ini diberikan agar siswa dapat beragumen, merespon, dan mengulang kembali hal-hal yang terdapat dalam cerpen.

Pelajaran menulis sudah diberikan sejak siswa menempuh pendidikan di sekolah dasar hingga sekolah menengah atas. Mengingat lamanya siswa mendapatkan pelajaran menulis di sekolah tentunya siswa sudah memiliki keterampilan yang baik dalam bidang menulis. Namun, kenyataan di lapangan menunjukkan keterampilan menulis siswa belum dikuasai dengan baik. Hal ini disebabkan oleh kesulitan siswa dalam menuangkan ideidenya ketika menulis.

Sesuai dengan hasil pengamatan yang peneliti lakukan di SMK Negeri 3 Singaraja ditemukan beberapa hal, yaitu: (1) seluruh kelas XI memperoleh materi yang sama dalam pembelajaran resensi cerpen berdasarkan kurikulum 2013, (2) saat pembelajaran bahasa Indonesia, khususnya pembelajaran resensi, guru memberikan pemahaman serta menyampaikan materi dengan baik agar terciptanya tujuan pembelajaran yang diinginkan, (3) siswa kesulitan dalam mengungkapkan ide, mengembangan judul, dan mengembangkan kalimat, (4) belum optimalnya kemampuan siswa dalam menulis, (5) siswa kurang tertarik terhadap pembelajaran menulis, (6) kurangnya motivasi dan keterlibatan siswa dalam menulis, serta (7) rendahnya respons siswa saat menulis, (8) adanya kendala-kendala yang dihadapi oleh guru dan siswa dalam pembelajaran menulis.

Hal-hal di atas disebabkan oleh beberapa faktor, salah satunya yaitu penggunaan metode pembelajaran yang kurang kreatif dan kurang inovatif. Hal ini juga diperkuat oleh penelitian Lubis (dalam Pohan, 2014:3) yang menyatakan bahwa 
salah satu faktor yang menyebabkan pembelajaran meresensi cerpen kurang tercapai adalah metode pembelajaran. Salah satu alternatif untuk mengatasi faktor-faktor di atas yaitu guru mengujicobakan metode pembelajaran yang sesuai dengan keadaan siswa demi tercapainya tujuan pembelajaran. Dengan demikian guru memilih metode pembelajaran yang tepat agar dalam menyampaikan materi bisa berjalan efektif dan menarik. Menurut Djamarah (2006) pemilihan metode merupakan hal yang sangat penting dan perlu diperhatikan karena metode adalah salah satu alat untuk mencapai tujuan. Pemilihan metode juga bisa dipengaruhi atau ditentukan oleh (1) usia siswa, (2) latar belakang budaya, (3)pengalaman siswa, (3) pengalaman guru dan tingkat keterampilannya, (5) tujuan belajar (Nurjaya, 2012:14-15). Dengan pemilihan metode pembelajaran yang tepat, kita dapat melihat keefektifan penggunaan metode itu sendiri.

Salah satu metode belajar partisipatif yang dapat digunakan untuk mengatasi faktor di atas adalah metode buzz group. Metode buzz group digunakan dalam kegiatan pembelajaran pemecahan masalah yang di dalamnya mengandung bagian-bagian khusus dalam masalah itu (Sudjana, 2006:124). Penggunaan metode buzz group bertujuan agar proses belajarmengajar lebih menyenangkan dan lebih mudah dipahami siswa. Selain itu, metode ini diharapkan menumbuhkan suasana kondusif, penuh perhatian, dan menghargai pendapat orang lain. Metode ini menuntut keaktifan siswa, sehingga sesuai dengan keadaan siswa yang memiliki kemampuan yang berbeda-beda. Siswa yang memiliki kemampuan yang berbeda akan saling membantu dalam menyelesaikan permasalahan dalam kelompoknya.

$$
\text { Metode buzz group yang }
$$

diujicobakan guru ini memiliki keunggulan yang berbeda dengan metode lainnya. Keunggulan metode ini yaitu, (1) mampu mendorong individu untuk memberikan sumbangan pemikiran melalui diskusi kelompok, (2)metode ini dapat menciptakan suasana yang menyenangkan, (3) metode ini juga mampu menghemat waktu, (4) metode ini dapat memberikan variasi dalam kegiatan pembelajaran, (5) peserta didik dapat terdorong untuk ikut serta sehingga memunculkan sikap yang percaya diri dalam diri siswa, (6) peserta didik mampu membagi tugas kepemimpinan untuk mengatur semua anggota kelompok (Slameto, 2001:104).

Efektivitas metode pembelajaran dapat dilihat dari seberapa besar daya serap siswa dalam memahami suatu konsep yang diperoleh dari data hasil tes dan praktek sebagai aplikasi dari pemahaman dan konsep yang didapatkan siswa. Efektivitas juga dapat diketahui melalui persentase keberhasilan siswa yang berupa aspek kognitif (penguasaan konsep), aspek afektif (tanggapan siswa), dan aspek psikomotorik (kerja siswa) pada saat melakukan proses pembelajaran. Berpijak dari hal-hal tersebut di atas, maka penulis memandang penting untuk mengetahui "Efektivitas Penggunaan Metode Buzz group dalam Pembelajaran Menulis Resensi Cerpen di SMK Negeri 3 Singaraja".

Bertolak dari hal di atas penelitian ini membahas mengenai (1) prestasi siswa dengan penggunaan metode buzz group dalam pembelajaran menulis resensi cerita pendek di kelas XI SMK Negeri 3 Singaraja, (2) respons siswa dengan penggunaan metode buzz group dalam pembelajaran menulis resensi cerita pendek di kelas $\mathrm{XI}$ SMK Negeri 3 Singaraja, dan (3) kendalakendala yang dialami oleh guru dan siswa saat menggunakan metode buzz group dalam pembelajaran menulis resensi cerita pendek di kelas XI SMK Negeri 3 Singaraja. Sesuai masalah tersebut, penelitian ini memiliki tujuan untuk (1) mendeskripsikan prestasi siswa dengan adanya penggunaan metode buzz group dalam pembelajaran menulis resensi cerita pendek di kelas XI SMK Negeri 3 Singaraja, mendeskripsikan respons siswa dengan adanya penggunaan metode buzz group dalam pembelajaran menulis resensi cerita pendek di kelas XI SMK Negeri 3 Singaraja, dan (3) mendeskripsikan kendala-kendala yang dialami oleh guru dan siswa saat 
menggunakan metode buzz group dalam pembelajaran menulis resensi cerita pendek di kelas XI SMK Negeri 3 Singaraja.

$$
\text { Adapun manfaat yang bisa }
$$

diperoleh dari penelitian ini dapat dibedakan menjadi dua, yakni manfaat teoretis dan manfaat praktis. Secara teoretis, hasil penelitian ini dapat menambah ilmu pengetahuan, terkait dengan keefektifan penggunaan metode pembelajaran, khususnya metode buzz group dalam pembelajaran menulis resensi cerpen. Secara praktis, penelitian ini bermanfaat bagi guru guna mengetahui keefektifan metode pembelajaran buzz group, khususnya dalam pembelajaran menulis resensi cerpen. Selain itu, hasil penelitian ini diharapkan dapat dijadikan strategi alternatif dalam mengelola pembelajaran. Penelitian ini juga bermanfaat untuk memperkaya metode pembelajaran dan memperbaiki metode pembelajaran untuk menghilangkan kebosanan dan kejenuhan siswa. Hal ini akan mengacu pada perhatian siswa, sehingga siswa dapat aktif dan berpartisipasi dalam pembelajaran. Bagi mahasiswa calon guru, mahasiswa calon guru dapat menggunakan penelitian ini sebagai bahan masukan saat melaksanakan proses belajar mengajar di kelas. Dengan demikian, penelitian ini dapat memberikan bayangan dalam kegiatan belajar mengajar yang akan dilaksanakan mahasiswa calon guru pada saat PPL (Program Pengalaman Lapangan) ataupun saat menjadi pendidik. Bagi sekolah, hasil penelitian ini juga bermanfaat bagi lembaga atau sekolah yang belum menggunakan metode pembelajaran dalam kegiatan belajar-mengajar. Penelitian ini dapat digunakan sebagai bahan bacaan dan acuan demi pelaksanaan pembelajaran menulis. Pihak sekolah dapat menciptakan kegiatan belajar-mengajar yang menarik dan tidak membosankan dengan menggunakan metode buzz group. Bagi siswa, penelitian ini dapat dijadikan referensi untuk menambah pengetahuan dan wawasan siswa, khususnya dalam pembelajaran menulis resensi cerpen. Bagi peneliti lain, penelitian ini dapat dijadikan sebagai acuan, pedoman, serta bahan perbandingan dalam melakukan penelitian sejenis.

\section{METODE PENELITIAN}

Penelitian ini menggunakan rancangan penelitian deskriptif kualitatif dan kuantitatif. Menurut Best (dalam Sukardi, 2008:15), penelitian deskriptif merupakan penelitian yang berusaha menggambarkan dan menginterpretasikan objek sesuai dengan keadaannya. Peneliti akan melaporkan keadaan objek yang alamiah atau apa adanya. Pada penelitian ini, peneliti tidak ikut serta atau tidak memberikan pengaruh terhadap kegiatan pembelajaran di dalam kelas. Peneliti hanya menggambarkan/mendeskripsikan kejadian nyata yang terjadi dalam kegiatan belajar-mengajar.

Selain itu, penelitian ini menggunakan rancangan penelitian kuantitatif, yaitu penelitian yang bertujuan mengukur objek atau fenomena sosial secara objektif. Dalam penelitian kuantitatif ini, fenomena diceritakan dengan menggunakan angka-angka, sedangkan dalam penelitian deskriptif kualitatif, fenomena diceritakan secara verbal (katakata).

Dalam kaitannya dengan penelitian yang dilakukan, rancangan penelitian kualitatif digunakan untuk mendeskripsikan kendala-kendala yang dihadapi guru dan siswa dalam menggunakan metode buzz group. Rancangan penelitian deskriptif kuantitatif digunakan untuk mendeskripsikan prestasi dan respons siswa terhadap penggunaan metode buzz group dalam pembelajaran menulis resensi cerita pendek.

Subjek penelitian memiliki kedudukan yang sentral dalam penelitian, karena pada subjek penelitian data tentang variabel yang diteliti berada dan diamati oleh peneliti. Menurut Suandi (2008:31), subjek penelitian adalah benda, hal, atau orang tempat variabel melekat, dan dapat dipermasalahkan dalam penelitian. Subjek dalam penelitian ini adalah guru bahasa Indonesia yang mengajar di kelas XI SMK Negeri 3 Singaraja dan siswa kelas XI SMK 
Negeri 3 Singaraja. Penentuan subjek penelitian ini menggunakan teknik sampling purposive. Sampling purposive adalah teknik penentuan sampel dengan tujuan tertentu. Peneliti menggunakan teknik penyampelan ini karena peneliti berusaha untuk memperoleh informasi dan data yang relevan dengan tujuan penelitian.

Objek penelitian merupakan sasaran untuk mendapatkan suatu data. Sesuai dengan pendapat Sugiyono (2010:13), objek penelitian merupakan sasaran ilmiah untuk mendapat data dengan tujuan dan kegunaan tertentu tentang sesuatu hal objektif, valid, reliable tentang suatu hal (variabel tertentu). Objek penelitian merupakan hal yang dikaji dalam penelitian. Objek penelitian ini adalah penggunaan metode buzz group dalam pembelajaran menulis resensi cerita pendek.

Pengumpulan data dalam penelitian dilakukan untuk mendapatkan data sesuai dengan masalah penelitian. Data yang dikumpulkan adalah data yang dapat digunakan untuk menjawab permasalahan yang dikaji dalam penelitian. Agar mendapatkan data yang relevan untuk menjawab permasalahan, maka diperlukan metode pengumpulan data yang tepat agar data yang diperoleh juga tepat dan relevan dengan permasalahan yang dikaji dalam penelitian. Natsir (1998:211) mengatakan bahwa metode pengumpulan data adalah prosedur yang sistematis dan standar untuk memperoleh data yang diperlukan, selalu ada hubungan antara metode pengumpulan data dengan masalah penelitian yang diperoleh. Metode pengumpulan data yang digunakan dalam penelitian ini adalah metode tes, kuesioner/angket, wawancara dan observasi. Metode tes digunakan oleh peneliti untuk mendapatkan data prestasi siswa. Metode wawancara digunakan peneliti untuk memperoleh data mengenai kendala-kedala guru dalam penggunaan metode buzz group dalam pembelajaran menulis resensi cerpen. Metode observasi digunakan untuk memperoleh data respons dan kendala-kendala yang dialami oleh guru dan siswa dengan digunakannya metode buzz group dalam pembelajaran menulis resensi cerpen di SMK Negeri 3 Singaraja. Metode angket/kuesioner digunakan untuk memperoleh data respons siswa terhadap pembelajaran menulis resensi cerita pendek dengan menggunakan metode buzz group. Analisis respons siswa dianalisis dengan teknik analisis deskriptif kualitatif dan kuantitatif. Analisis kuantitatif dilakukan berdasarkan skor rata-rata $(\bar{X})$ dari skor respons siswa, mean ideal $(\mathrm{Mi})$, dan standar deviasi ideal (SDi). Adapun kreteria penggolongan respons siswa terlihat pada tabel di bawah ini.

Tabel 01 Kreteria Penggolongan Skor Respons Siswa

\begin{tabular}{|l|l|}
\hline \multicolumn{1}{|c|}{ Skor } & \multicolumn{1}{|c|}{ Kriteria } \\
\hline $\bar{X}>\mathrm{Mi}+1,5 \mathrm{SDi}$ & Sangat Positif \\
\hline $\begin{array}{l}\mathrm{Mi}+0,5 \mathrm{SDi}<\bar{X} \leq \mathrm{Mi} \\
+1,5 \mathrm{SDi}\end{array}$ & Positif \\
\hline $\begin{array}{l}\mathrm{Mi}-0,5 \mathrm{SDi}<\bar{X} \leq \mathrm{Mi} \\
+0,5 \mathrm{SDi}\end{array}$ & Cukup Positif \\
\hline $\begin{array}{l}\mathrm{Mi}-1,5 \mathrm{SDi}<\bar{X} \leq \mathrm{Mi} \\
-0,5 \mathrm{SDi}\end{array}$ & Kurang Positif \\
\hline $\bar{X}<\mathrm{Mi}-1,5 \mathrm{SDi}$ & $\begin{array}{l}\text { Sangat Kurang } \\
\text { Positif }\end{array}$ \\
\hline
\end{tabular}

(Sumber Nurkancana,1999)

Skor rata-rata $(\bar{X})$ respons siswa dicari dengan cara membagi jumlah skor respons siswa dengan jumlah siswa yang memberikan respons. Rumus yang digunakan untuk mencari skor rata-rata $(\mathrm{x})$ respons siswa adalah sebagai berikut.

$$
\bar{X}=\frac{\sum \mathrm{n}}{\mathrm{n}}
$$

$$
\begin{aligned}
& \frac{\text { Keterangan }}{\bar{X}}=\text { Rata-rata skor respon siswa } \\
& \sum \mathrm{n}=\text { Jumlah skor siswa }
\end{aligned}
$$


$\mathrm{N}$ = Jumlah yang memberikan respon

$\mathrm{Mi}=$ Mean Ideal

Mi diperoleh dengan menggunakan rumus sebagai berikut.

$\mathrm{Mi}=1 / 2$ ( skor maksimal ideal + skor minimum ideal)

$\mathrm{SDi}=$ Standar devisiasi ideal

SDi diperoleh dengan rumus sebagai berikut.

$\mathrm{SDi}=1 / 3$ (Mi)

Skor tertinggi ideal untuk respon siswa melalui penyebaran angket adalah 50, sedangkan skor terendah ideal adalah 10. Oleh karena itu, diperoleh Mi dan SDi sebagai berikut.

$\mathrm{Mi}=1 / 2(50+10)$

$=1 / 2(60)$

$=30$

$\mathrm{SDi}=1 / 3(30)=10$

Berdasarkan perhitungan tersebut, hasil yang diperoleh dikonversikan berdasarkan pedoman berikut.

Tabel 02. Konversi Skor Respon Siswa

\begin{tabular}{|l|l|}
\hline \multicolumn{1}{|c|}{ Skor } & \multicolumn{1}{c|}{ Kreteria } \\
\hline $\bar{X}>45$ & Sangat Positif \\
\hline $35 \leq \bar{X}<45$ & Positif \\
\hline $25 \leq \bar{X} \leq 35$ & Cukup Positif \\
\hline $15 \leq \bar{X}<25$ & Kurang Positif \\
\hline $\bar{X}<15$ & $\begin{array}{l}\text { Sangat Kurang } \\
\text { Positif }\end{array}$ \\
\hline
\end{tabular}

Hasil perhitungan skor respons siswa ini menunjukkan tanggapan siswa terhadap penggunaan metode buzz group dalam pembelajaran menulis resensi cerita pendek.

Instrumen penelitian yang peneliti gunakan adalah (1) lembar tes, (2) kuesioner/angket, dan (3) pedoman wawancara (4) lembar observasi. Lembar tes digunakan untuk mendapatkan gambaran sesuai dengan rumusan masalah dan tujuan yang pertama, yaitu prestasi siswa dalam pembelajaran menulis resensi cerita pendek menggunakan metode buzz group di kelas XI SMK Negeri 3 Singaraja. Kuesioner/angket dan pedoman observasi digunakan untuk memperoleh gambaran sesuai dengan rumusan masalah yang kedua mengenai respons siswa terhadap penggunaan metode buzz group dalam pembelajaran menulis resensi cerita pendek di kelas XI SMK Negeri 3 Singaraja. Pedoman wawancara dan pedoman observasi digunakan untuk mendapatkan gambaran sesuai dengan rumusan masalah ketiga mengenai kendala-kendala yang dialami guru saat menggunakan metode buzz group dalam pembelajaran menulis resensi cerita pendek, sedangkan kendalakendala yang dihadapi siswa dalam pembelajaran menulis resensi cerita pendek menggunakan instrumen lembar observasi.

Teknik analisis data yang peneliti gunakan adalah teknik deskriptif kualitatif dan kuanlitatif. Teknik deskriptif kualitatif digunakan untuk menganalisis data mengenai kendala yang dialami guru dan siswa saat menggunakan metode buzz group dalam pembelajaran menulis resensi cerita pendek, sedangkan teknik deskriptif kuantitatif digunakan untuk menganalisis data mengenai prestasi dan respons siswa terhadap penggunaan metode buzz group. Menurut Sugiyono (2010:246), aktivitas dalam analisis data kualitatif dilakukan secara interaktif dan berlangsung secara terus menerus sampai tuntas, sehingga datanya sudah jenuh. Aktivitas yang akan peneliti lakukan dalam analisis data yaitu (1) reduksi data, (2) penyajian data, dan (3) verifikasi data (penarikan simpulan).

Pada kegiatan reduksi data, peneliti merangkum, memilih hal-hal pokok yang berkaitan dengan masalah yang dikaji yaitu, (1) prestasi siswa dengan penggunaan metode buzz group dalam pembelajaran menulis resensi cerita pendek di SMK Negeri 3 Singaraja, (2) respons siswa dengan penggunaan metode buzz group dalam pembelajaran menulis resensi cerita pendek di SMK Negeri 3 Singaraja, (3) kendala-kendala yang dialami oleh guru dan siswa saat penggunaan metode buzz group dalam pembelajaran menulis resensi cerita pendek di SMK Negeri 3 Singaraja. 
Pada kegiatan penyajian data, data yang telah direduksi disajikan dengan teks yang bersifat naratif. Dalam penyajian data ini, data yang didapat akan dihubungkan dengan teori-teori yang relevan, sehingga nantinya mampu membantu peneliti dalam memecahkan masalah penelitian.

Setelah dilakukan reduksi dan penyajian data, selanjutnya dilakukan penyimpulan. Penyimpulan yang dilakukan harus dapat menjawab semua masalah yang diangkat dalam penelitian. Dengan demikian hasil akhir nanti akan diketahui efektifitas penggunaan metode buzz group dalam pembelajaran menulis resensi cerpen di SMK Negeri 3 Singaraja

\section{HASIL DAN PEMBAHASAN}

Hasil penelitian ini adalah hal-hal yang berkenaan dengan (1) prestasi siswa dengan penggunaan metode buzz group dalam pembelajaran menulis resensi cerita pendek di kelas XI SMK Negeri 3 Singaraja, (2) respons siswa dengan penggunaan metode buzz group dalam pembelajaran menulis resensi cerita pendek di kelas XI SMK Negeri 3 Singaraja, dan (3) kendalakendala yang dialami oleh guru dan siswa saat menggunakan metode buzz group dalam pembelajaran menulis resensi cerita pendek di kelas XI SMK Negeri 3 Singaraja Dalam penelitian ini dilakukan tes menulis resensi cerita pendek untuk mengetahui prestasi siswa. Dari 121 orang siswa, sebanyak 6 orang siswa (4.95\%) mendapatkan nilai menulis resensi cerita pendek dengan kategori sangat baik. Siswa menuliskan struktur resensi, berupa identitas buku yang diresensi, pendahuluan, intisari, kekurangan dan kelebihan, dan penutup. Bahasa yang digunakan dalam tulisan pun sudah baik, meskipun masih ada kekurangan dan isi resensi sudah sesuai dengan cerita pendek yang diresensi yaitu cerita pendek robohnya surau kami, karya A.A. Navis. Selain itu, sebanyak 91 orang siswa $(75.22 \%)$ mendapatkan nilai dengan kategori baik. Siswa menuliskan struktur resensi, berupa identitas buku yang diresensi, pendahuluan, intisari, kekurangan dan kelebihan, dan penutup.
Secara teoretis, hal ini didukung oleh pernyataan Suherli (2017:228) yang menyatakan bahwa kerangka penulisan resensi meliputi judul, identitas buku, pendahuluan, ulasan, dan penutup. Namun, ada beberapa yang menuliskan identitas buku yang diresensi kurang lengkap, sehingga nilai yang diperoleh berkurang. Bahasa yang digunakan dalam tulisan pun sudah baik, meskipun masih ada kekurangan dan isi resensi sudah sesuai dengan cerita pendek. Terdapat 11 orang siswa $(10.74 \%)$ mendapatkan nilai dengan kategori cukup. Kategori penilaian tersebut dilihat dari tulisan siswa yang menuliskan identitas buku kurang lengkap, masih terdapat kesalahan-kesalahan penggunaan bahasa, dan pendahuluan yang tidak sesuai dengan hal-hal yang diresensi. Bahkan ada 13 orang siswa $(9.09 \%)$ yang mendapatkan nilai dengan kategori kurang. Hal ini karena siswa tidak menuliskan identitas buku dengan lengkap, isi resensi tidak sesuai, dan tidak menuliskan struktur resensi secara lengkap.

Berdasarkan hasil kuesioner dapat disimpulkan bahwa respons siswa terhadap penggunaan metode buzz group dalam pembelajaran menulis resensi cerita pendek positif. Hal tersebut terlihat dari hasil kuesioner siswa kelas XI SMK Negeri 3 Singaraja. Dari 121 orang siswa, sebanyak 37 orang siswa memberikan respons sangat positif, 80 orang siswa (66.13\%) memberikan respons positif, dan 4 orang siswa (3.30\%) memberikan respons cukup positif, serta tidak ada siswa $(0 \%)$ yang memberikan respons kurang positif dan sangat kurang positif. Jadi, dari lima kelas yang telah dibagikan kuesioner, dapat disimpulan bahwa sebagian besar siswa memberikan respons yang positif terhadap penggunaan metode buzz group dalam pembelajaran menulis resensi cerita pendek. Siswa merasa sangat senang melakukan kegiatan pembelajaran ini karena dapat mengemukakan pendapat dan memberikan masukan untuk teman. Selain itu, siswa juga aktif dalam kegiatan pembelajaran di kelas. Hal tersebut sejalan dengan pendapat Harvey dan Smith (dalam Ahmadi, 1999: 164) yang mendefinisikan 
respons merupakan bentuk kesiapan dalam menentukan sikap baik dalam bentuk positif atau negatif terhadap objek atau situasi.

Selain dari hasil kuesioner, respons siswa juga terlihat saat dilaksanakan observasi pada kegiatan awal, kegiatan inti, dan kegiatan akhir pelajaran. Siswa menyimak penjelasan, mencatat materi yang diberikan, dan melaksanakan langkah-langkah pembelajaran sesuai dengan arahan guru. Respons siswa tampak dari keantusiasan dalam pembelajaran, yaitu siswa semangat, senang, nyaman, mampu berinteraksi dengan teman, percaya diri, dan tidak cepat bosan. Hal tersebut sejalan dengan pendapat Uno (2007:104), bahwa daya tarik pembelajaran biasanya diukur dengan mengamati kecenderungan (respons) siswa untuk belajar. Secara teoretis, temuan ini didukung oleh pernyataan Trianto (2007 : 207) yang memaparkan bahwa kelebihan metode buzz group adalah metode ini dapat menciptakan suasana yang menyenangkan dan peserta didik dapat terdorong untuk ikut serta sehingga memunculkan sikap yang percaya diri dalam diri siswa.

Dari wawancara yang telah dilakukan dengan limaorang guru bahasa Indonesia di SMK Negeri 3 Singaraja terlihat bahwa masing-masing guru mempunyai kendala yang berbeda. Hal ini terjadi karena kemampuan siswa yang berbeda, situasi lingkungan kelas yang berbeda, alokasi waktu dalam pembelajaran yang berbeda, dan minat belajar siswa yang berbeda. Dari lima orang guru yang diwawancarai, semuanya terkendala waktu dalam mengajarkan materi resensi cerita pendek menggunakan metode buzz group. Pembelajaran menulis resensi tidak cukup hanya 1 kali pertemuan (2X45menit). Selain itu, waktu yang disediakan untuk berdiskusi sedikit. Hal tersebut juga didukung oleh pendapat Trianto (2007:104) bahwa waktu diskusi terlalu singkat, sehingga diskusi kurang efektif. Berdasarkan hal itu, keterampilan guru dalam mengelola kelas sangat diperlukan dalam kegiatan belajarmengajar. Selain itu, kendala dari lingkungan juga dialami oleh guru.Kendala tersebut yaitu siswa yang berada di kelas sebelahnya ribut, sehingga siswa tidak konsentrasi dalam belajar. Kendala yang terakhir dialami guru yaitu kemampuan siswa yang masih kurang dalam menulis dan ada beberapa siswa kurang aktif dalam bertanya dan menyampaikan gagasan, sehingga siswa perlu dikontrol agar berdiskusi dan menulis resensi.

Selain itu, kendala-kendala yang dialami siswa dalam pembelajaran menulis resensi cerita pendek menggunakan metode buzz group yaitu siswa terkendala waktu. Waktu yang disediakan untuk pelajaran bahasa Indonesia yaitu 2X45 menit. Namun sebelum menulis siswa harus membaca terlebih dahulu materi/bahan yang akan digunakan dalam pembelajaran menulis resensi, sehingga waktu yang disediakan harus benar-benar digunakan dengan efisien. Keterampilan membaca dan menulis yang dimiliki siswa sangat diperlukan dalam pembelajaran ini. Kemudian, selama dilaksanakan observasi terlihat ada beberapa siswa melamun, pandangan mengarah keluar, bercerita dengan teman sebangkunya, dan izin ke kamar mandi. Hal-hal tersebut menyebabkan siswa tidak bisa konsentrasi dalam kegiatan pembelajaran, sehingga hasil yang didapatkan tidak sesuai dengan yang diharapkan. Hal ini sejalan dengan pendapat Widiaswono (2017:197) yang menyatakan akibat dari tidak bisa konsentrasi penuh atau gagal fokus yaitu semakin menurun prestasi belajar dan siswa tidak akan bisa memahami materi pelajaran dengan baik.

Berdasarkan pemaparan di atas, keefektifan penggunaan metode pembelajaran tergantung pada kesesuaian metode pembelajaran dengan beberapa faktor yaitu tujuan pembelajaran, materi pembelajaran, kemampuan guru, kondisi siswa, sumber atau fasilitas, situasi kondisi dan waktu. Hal lain yang menunjukkan keefektifan penggunaan metode pembelajaran terlihat dari hasil belajar dan respons siswa. Hasil belajar siswa menggunakan metode buzz group tergolong baik. Selain itu, penggunaan metode buzz group juga memperoleh 
respons yang positif dalam pembelajaran menulis resensi cerita pendek. Dengan demikian, penggunaan metode buzz group efektif digunakan dalam pembelajaran menulis resensi cerita pendek.

\section{SIMPULAN DAN SARAN}

Berdasarkan hasil penelitian mengenai penggunaan metode buzz group dalam pembelajaran menulis resensi cerita pendek pada siswa kelas XI SMK Negeri 3 Singaraja dapat diambil simpulan sebagai berikut.

Pertama, prestasi siswa yang didapatkan siswa dalam pembelajaran menulis resensi cerita pendek di kelas XI SMK Negeri 3 Singaraja dengan menggunakan metode buzz group memperoleh hasil yang tergolong baik. Hal tersebut dapat dilihat dari rata-rata nilai siswa adalah 91,22 berada pada kategori baik. Hasil tersebut membuktikan bahwa penggunaan metode buzz group efektif digunakan dalam pembelajaran menulis resensi cerita pendek.

Kedua, respons siswa terhadap penggunaan metode buzz group dalam pembelajaran menulis resensi cerita pendek di kelas XI SMK Negeri 3 Singaraja tergolong positif. Hal tersebut dapat dilihat dari respons yang diberikan siswa dengan rata-rata respons 66, 13 yang berada pada kategori respons positif. 
Hasil respons tersebut membuktikan bahwa penggunaan metode buzz group dalam pembelajaran menulis resensi cerita pendek efektif. Dari lima kelas yang diteliti oleh peneliti dalam pelaksanaan pembelajaran menulis resensi cerita pendek, siswa sudah memberikan respons yang positif. Hal itu terlihat dari, respons siswa dari kegiatan awal, kegiatan inti, dan kegiatan akhir pelajaran.

Ketiga, pembelajaran menulis resensi menggunakan metode buzz group sudah berjalan dengan baik. Akan tetapi, guru dan siswa masih mengalami kendala-kendala saat pelaksanaan pembelajaran di kelas. Kendala tersebut berasal dari siswa, dari segi waktu, lingkungan, dan kendala lainnya yang dialami oleh guru yang mengajar di masing-masing kelas XI MM 3, TGB 2, TKR 1, TKJ 2, dan TAV 1. Selain itu, kendala-kendala yang dialami siswa dalam pembelajaran menulis resensi cerita pendek menggunakan metode buzz group yaitu siswa terkendala waktu dan siswa tidak konsentrasi dalam mengikuti pembelajaran di kelas.

Berdasarkan pembahasan dan
simpulan di atas, saran yang dapat
disampaikan dalam penelitian ini adalah
sebagai berikut.
Pertama, khususnya guru bahasa
Indonesia agar terus belajar
mengembangkan metode pembelajaran yang sesuai dengan materi, agar dalam pembelajaran khususnya pembelajaran menulis resensi siswa menjadi lebih tertarik dan bersemangat untuk mengikuti proses belajar-mengajar. Dengan demikian, pembelajaran menjadi menyenangkan dan siswa pun tidak malu mengemukakan pendapatnya di dalam kelas.

Kedua, bagi guru lain yang akan menerapkan metode buzz group sebaiknya memperhatikan dan mempersiapkan segala sesuatu yang berkaitan dengan pelaksanaan pembelajaran di kelas. Guru juga hendaknya mempersiapkan alokasi waktu, menguasai materi, dan mengelola kelas dengan baik, sehingga kegiatan pembelajaran dapat berjalan lancar sesuai dengan tujuan yang diinginkan

Ketiga, kepada peneliti lain, paparan yang terdapat dalam penelitian ini dapat dijadikan bahan dalam meneliti masalah lain yang sejenis dengan penelitian ini secara lebih lanjut. Peneliti meyakini bahwa dalam penelitian ini masih ada hal yang belum dibahas dan belum diselesaikan. Oleh sebab itu, diharapkan pengadaan penelitian lanjutan yang sejenis dengan penelitian ini, sehingga diperoleh hasil yang lebih meyakinkan serta sebagai sumbangan bagi guru untuk bahan kajian dan peningkatan mutu pendidikan.

\section{DAFTAR PUSTAKA}

Ahmadi, Abu. 1992. Psikologi Umum. Jakarta : PT Raja Grafindo.

Akhadiah, Sabarti, dkk. 1998. Pembinaan Kemampuan Menulis Bahasa Indonesia.Jakarta: Erlangga

Barnawi dan Arifin. 2016. Teknik Penulisan Karya IImiah. Yogyakarta: Ar-ruzz Media

Djamrah, Syaiful Bahri dan Zain Aswan. 2006. Strategi Belajar Mengajar. Jakarta: PT Rineka Cipta.

Gie, The Liang. 2002. Terampil Mengarang. Yogyakarta: Andi.

Keraf, Gorys. 1980. Komposisi Sebuah Pengantar kepada Kemahiran Bahasa.Flores: Nusa Indah.

Keraf, Gorys. 2004. Komposisi. Flores: Nusa Indah.

Pohan, Eli Yulidar. 2014. "Pengaruh Model Pembelajaran Collaborative learning terhadap kemampuan Menulis Resensi Cerpen oleh Siswa Kelas XI SMA Persiapan Stabat". Skripsi 
(tidak diterbitkan). Sumatra Utara : Universitas Negeri Medan.

Nazir, Moh. 2003. Metode Penelitian. Jakarta: Ghalia Indonesia.

Nurjaya, Gede. 2012. Bahan Ajar Metode Pembelajaran Bahasa dan Sastra Indonesia. Singaraja: Universitas Pendidikan Ganesha.

Nurkancana, Wayan. 1990. Evaluasi Hasil Belajar. Surabaya : Usaha Nasional.

Pohan, Eli Yulidar. 2014. "Pengaruh Model Pembelajaran Collaborative Learning terhadap Kemampuan Menulis Resensi Cerpen oleh Siswa Kelas XI SMA Stabat Tahun Pelajaran 2013/2014". Terdapat dalam

http://ejournal.iainkendari.ac.id/altadib/article/view/550/535/diakses pada 31/12/2017/Pukul 9.48 Wita

Slameto. 2001. Proses Belajar Mengajar dalam SKS. Jakarta: Bumi Aksara.

Sudjana. 2005. Metode dan Teknik Pembelajaran Partisipatif. Bandung: Falah Production.

Sugiyono. 2010. Metode Penelitian Pedidikan Pendekatan Kualitatif, Kuantitatif dan R\&D. Bandung: Alfabeta

Suherli, dkk. 2017. Bahasa Indoesia. Jakarta: Kementerian Pendidikan dan Kebudayaan.

Sukardi. 2008. Metodelogi Penelitian Pendidikan Kompetensi dan Praktiknya. Yogyakarta : PT. Bumi Aksara.

Tarigan, Hendry Guntur. 1997. Menulis sebagai suatu Keterampilan Berbahasa. Bandung : Angkasa.
Trianto. 2007. Model-model Pembelajaran Inovatif Berorientasi Konstruktivistik. Jakarta: Prestasi Pustaka.

Uno, Hamzah B. 2007. Perencanaan Pembelajaran. Jakarta: PT Bumi Aksara.

Wendra, I Wayan. 2012. Buku Ajar Keterampilan Berbicara. Singaraja: Universitas Pendidikan Ganesha.

Widiasworo, Erwin. Masalah-masalah Peserta Didik dalam Kelas dan Solusinya. Yogyakarta : Araska. 